\title{
TEACHING VOCABULARY USING FLASHCARD TO YOUNG LEARNER
}

\author{
Siti Ngarofah ${ }^{1}$, Ani Sumarni ${ }^{2}$ \\ ${ }^{1}$ IKIP Siliwangi \\ ${ }^{2}$ IKIP Siliwangi \\ 1'laststory1428@gmail.com , ${ }^{2}$ sumarniani969@gmail.com
}

\begin{abstract}
This research entitled " teaching vocabulary using flashcard to young learners" is a study to investigate the influence of using flashcard in teaching vocabulary to students of grade four in elementary school. This study was done using pre-experimental research. There are three steps in doing research design. First, the writer gave pretest to the students of elementary school grade two as the dependent variable. Second, the writer implicate the treatment to the subjects by teaching vocabulary using flashcard. Final steps, the writer gave subjects posttest. The results of the research showed that there is an improvement in student's vocabulary mastery after the students were thought vocabulary mastery using flashcard. The students of elementary school grade two could memorize and understand easily and they were encouraged to learn English. Thus, the researcher could conclude that using flashcard in teaching vocabulary to the students grade two is recommended as teaching program to learn English.
\end{abstract}

Keywords: Teaching Vocabulary, Flashcard, Young Learner

\section{INTRODUCTION}

English is an International languange, so people need to study this languange for communicating with people in the world. To make a good communication, people should master vocabularies, grammar and correct pronounciation which can make it easier for people to understandable by the listeners. According to (Richards, 2001) one of important aspects in learning foreign languange is vocabulary.

English has been learned starting from elementary school to senior high school and of course at university.

They should learn English and be fluent in English for communication with many people in the world who have different languange easily and also it would be very useful when we go travelling around the world. Based on that case, most people around the countries set English as the one of compulsory subject should be learned at school.

In Indonesia, English is a foreign languange. English has been stated as the first foreign languange in Indonesia. In learning foreign languange, vocabulary as one of essential things that should be considered even more important than grammar "Without grammar very little can be conveyed, without vocabulary nothing can be conveyed" (Wilkins, 1972) The more people know the vocabulary the more effective communication will be. According to this term people should enrich their vocabulary as much as possible. Beside mastering vocabulary, the pronounciation of each word and grammatical structure also must be concerned to prevent misunderstanding or misconception between the speakers and listeners. 
There are some ways to enrich vocabulary such as using media which can be implicated for teaching learning English vocabulary. One of them is flashcard. Flashcard as the media in teaching vocabulary using flashcard can improve student's attention, thus make vocabulary mastery using flashcard as one of effective ways. Flashcard is one media that can attract student's attention and encourage them to learn and interested in English.

The writer is interested in doing research on the topic about using flachcard in teaching vocabulary to the students of elementary school. The writer want to prove whether or not flashcard are effective to improve student's vocabulary mastery through experimental research design. Therefore, the title of the research is "Teaching vocabulary using Flashcard to Young learners". The writer is interested in doing research on the technique used in teaching vocabulary to young learners. This research is important because it implicated media to teach vocabulary to young learners. This research described the media used in the fourth grade students of SD Muslimin Peusi Cililin in teaching vocabulary. That is why the teacher should find a kind of media which interest students to learn vocabulary in a fun way. People also believe if the students can perceive English as a fun subject, it is easy for them to absorb the material.

\section{Teaching}

Teaching is the process to give guidance to the learners to reach the objective of learning. Teaching know as "instruction" means the process that make someone do learning. Teaching is the media in learning process which includes the behavior through pre learned.

Teaching is an exciting job. Today many references help teacher to get some solutions of problems in teaching learning process. The teacher can use some references to gain some techniques in teaching classroom. Teaching is an occasion when your prime purpose is to help students to be able to understand factual information, or concepts, or procedures, or to solve problem, or to analyze the result such as data because these ( and other ) type knowledge are common to all subject areas".

Teaching considered as a creating situation where students expected in learning effectively. Teaching will be successful when the learners have the meaningful lesson. Teacher is not viewed from how teacher explains the contents of the lesson but the teacher should know how facing the students, helping them to make solution for the problem, managing the class, organizing the lesson, arranging the classroom activity, organizing learning assessment and deducing method or media.

According to (Brown, 2000) teaching is showing or helping someone to learn how to do something, giving instruction, guiding in the study of something, providing with knowledge, causing to know or understand.

\section{Vocabulary}

A person's vocabulary is the set of words to understand a language which are familiar to that person. The vocabulary is usually developed with the age, and serves as a useful and fundamental tool for communicating and acquiring the knowledge. Enrich an usefull vocabulary is one of the basic challenges in learning a second language.

Language consist of skills ( listening, speaking, reading, writing ) and sub skills (pronunciation, grammar, and vocabulary). Word are important part in our life. We think with 
words we also speak, listen, read, and write words. Words help us to communicate in our ideas. Expanding the vocabulary is one of the most useful way learner can implicate.

Word are the basic units of language from without a understable vocabulary, one will meet some difficulties to communicate in effective way or express some ideas. Having limited vocabularies are also the obstacles that give students some trouble from learning the foreign language. If learner do not know how to enrich their vocabularies, they will lose their motivation in learning.

Words regarded as most important part in learning language. Related to that matter, Michael McCarthy, quoted from Verneer stated. The key to understanding and being understood is assigning word. The large influence of learning a new language consists of learning words in foreign languange. Grammatical knowledge does not make of great proficiency in a language. (Verneer, 1992)

From Information above, the writer conclude that when someone learns English, the important thing they should be mastered is vocabularies.

\section{Types of vocabulary}

According to (Kamil, 2005) " Vocabulary is knowledge of meaning of words". Knowledge of words comes in at least two form: oral and print vocabulary.

a. Oral vocabulary includes those words that they recognize and use in listening and speaking.

b. Print vocabulary is a set of words that they assign and use in reading and writing.

Knowledge of words includes two kinds : productive and receptive vocabulary.

a. Productive vocabulary

Productive vocabulary is a set of words that frequently in use in writing or speaking. They are words that are popular, familiar, and frequently used.

b. Receptive vocabulary

Receptive or recognition vocabulary is a set of words for which an individual can indicate meaning when listening or reading. These are words that are often less popular to students and less frequent in implication of communication.

\section{The Importance of vocabulary}

Learning vocabulary is pretty important, since vocabulary is a vital and an important thing in communication. It can link listening, speaking, reading, and writing skill. Hence, student should learn vocabulary as early as possible.

(Lewis. M., 1993) states, "Lexis is the core or heart of language ." While vocabulary is the most important thing for understanding-knowing names for things, actions, and concepts. Someone can understand what other people say (listening skill), he can understand the written words ( reading skill) and written form ( writing skill) by mastering vocabulary.

From their statement above, it can be conclude that vocabulary is the core of language and must be mastered by people in learning integrating four aspects of language skill, such as listening, speaking, reading and writing. 
In addition palmer in (Richards, 2001) states," Vocabulary was one of the most essential aspects of foreign language." It can be concluded that vocabulary is one of the most essential factor in instruction activity about foreign language, because as mentioned above vocabulary is the core of language and people need to mastered it.

\section{Flashcard as Teaching Strategy}

Flashcards are included the best methods to use for learning and memorizing information. People can use flashcard to learn English or ather subject in class, such as vocabulary, mathematical equation and formulas, terms, and definitions or main idea and topics, TCL/The Learning Centre . Flashcard is a media as cards consist of information, as words or numbers, on either or both sides, used in classroom instruction or in special study. Flashcard can bear vocabulary, historical dates, formulas or any subject matter that can be learned via a question-and-answer format. Flashcard are widely used as a learning drill to aid memorization by way of spaced repetition.

Flashcard are sample picture on a piece of paper. It is possibly the most widely used visual aid in languange teaching. In this case, the teacher can make it by themselve or buy it at the bookstore. In this case, flashcard are small picture and the researchers makes them with size $12 \times 8 \mathrm{~cm}$. Flashcard are useful for teaching vocabulary especially for young learner. It can be enjoying and colorful media and children are more interested to learning vocabulary.

\section{The use of Flashcards}

There are some advantages of flash cards were as follows:
a. practicing are important questions
b. writing a sentence or story
c. describing a picture
d. arranging the words list in alphabet
e. combining the opinions
f. to get inspiration on writing a fable
g. playing cards.

When use flashcards the students choose one card which familiar to them and then she or he should describe it.

\section{The Characteristics of Young Learners}

In a blog cited by writer, she stated that there are some children's special characteristics in learning the languange. They are as following:

1. children respond the languange well through concrete things (visual things) rather than abstract things.

2. To stimulate students' thinking, they need some physical movements and activities

3. Children will be enthusiatic if they are taught using fun activities or being involved in activities.

4. Children love to pay, and learn best with enjoying activities.

5. Children learn well through something that is close to their culture.

6. Children like to work together. 


\section{METHOD}

This research is conducted to see if the treatments increase the students's achievement in vocabulary. Thus, to get a result of this research, the field study was done in three steps. The first step is the implicating of pretest calculating the dependent variable in this case is the students of elementary school grade two. The next step is the application of the experimental treatment to the subjects, the researcher thought vocabulary using flashcard and the final steps is the calculation of a posttest measuring the result of the tesst from dependent variable. Differences due to application of the experimental treatment are then determined by using comparison pretest and postest scores (Borg, 1979)

Firstly, a researcher gives English vocabulary pretest to a group of students, provides some sort of treatment to the group. The researcher thought English vocabulary using flashcard. Then the researcher gave the posttest. The result of pretest and posttest means were compared to determine whether learning took place.

During the research, the flashcard contained English vocabulary about "things in the classroom" , was given to 30 students of elementary school in Cililin. The pretest was done to measure students's achievement in vocabulary before giving the treatment by teaching vocabulary using flashcard. Then, the post-test was done to measure the students's achievement after the Implementation of teaching about vocabulary using flashcard. The result can be implicated to figure out whether the Implementation of teaching program could improve students's vocabulary or not.

\section{RESULTS AND DISCUSSION}

\section{Results}

To know the result of test ( pre-test and post-test) the writer makes the table of the student's scores in the classrooms. The writer did not attach the student's names but their score are as follow :

Table 1. Number of Student's after Pretest and Posttest

\begin{tabular}{cccc}
\hline No & Pretest & Postest & Gained score \\
\hline 1 & 30 & 70 & 40 \\
2 & 50 & 80 & 30 \\
3 & 33 & 85 & 52 \\
4 & 40 & 79 & 39 \\
5 & 25 & 82 & 57 \\
6 & 42 & 87 & 45 \\
7 & 31 & 80 & 49 \\
8 & 32 & 90 & 58 \\
9 & 36 & 84 & 48 \\
10 & 55 & 80 & 25 \\
11 & 37 & 95 & 58 \\
12 & 30 & 95 & 65 \\
13 & 45 & 80 & 35 \\
14 & 38 & 78 & 40
\end{tabular}




\begin{tabular}{llll}
15 & 48 & 82 & 34 \\
16 & 46 & 89 & 43 \\
17 & 26 & 94 & 68 \\
18 & 53 & 80 & 27 \\
19 & 54 & 82 & 28 \\
20 & 23 & 88 & 65 \\
21 & 39 & 79 & 40 \\
22 & 41 & 85 & 44 \\
23 & 44 & 90 & 46 \\
24 & 50 & 95 & 45 \\
25 & 21 & 81 & 60 \\
26 & 30 & 84 & 54 \\
27 & 36 & 85 & 49 \\
28 & 27 & 79 & 52 \\
29 & 32 & 86 & 54 \\
30 & 49 & 84 & 35 \\
\hline
\end{tabular}

Table 2. Tests of Normality

\begin{tabular}{lccccccc}
\hline & \multicolumn{3}{c}{ Kolmogorov-Smirnov $^{\mathrm{a}}$} & \multicolumn{3}{c}{ Shapiro-Wilk } \\
& Statistic & Df & Sig. & Statistic & df & \multicolumn{1}{c}{ Sig. } \\
$\begin{array}{l}\text { Pretest kemampuan } \\
\text { vocabulary }\end{array}$ & .117 & 30 & $.200^{*}$ & .952 & 30 & .189 \\
$\begin{array}{l}\text { postest kemampuan } \\
\text { vocabulary }\end{array}$ & .149 & 30 & .089 & .896 & 30 & .007 \\
$\begin{array}{l}\text { Gained kemampuan } \\
\text { vocabulary }\end{array}$ & .068 & 30 & $.200^{*}$ & .978 & 30 & .775 \\
\hline
\end{tabular}

a. Lilliefors Significance Correction

Based on test results on spss application (version 21) above can be concluded, vocabulary test with flash card is normally distributed, because Kolmogorov-Smirnova Pretest 200 result, Postest 089 and result of Shapiro-Wilk Pretest 189, Postest 007 (Criteria: if sigma > 0.05 then the study is normally distributed).

\section{Parametric test}

\section{T-Test}

Table 3. One-Sample Statistics

\begin{tabular}{lrrrr}
\hline & $\mathrm{N}$ & Mean & $\begin{array}{c}\text { Std. } \\
\text { Deviation }\end{array}$ & \multicolumn{1}{c}{$\begin{array}{c}\text { Std. Error } \\
\text { Mean }\end{array}$} \\
$\begin{array}{l}\text { kemampuan vocabulay } \\
\begin{array}{l}\text { pretest } \\
\text { kemampuan vocabulay } \\
\text { postes }\end{array}\end{array}$ & 30 & 38.10 & 9.743 & 1.779 \\
\hline
\end{tabular}

Table 4. One Sample Test

Test Value $=0$ 


\begin{tabular}{lrrrrrr}
\hline & $\mathrm{t}$ & Df & $\begin{array}{c}\text { Sig. (2- } \\
\text { tailed) }\end{array}$ & $\begin{array}{c}\text { Mean } \\
\text { Differenc } \\
\text { e }\end{array}$ & \multicolumn{2}{c}{$\begin{array}{c}\text { 95\% Confidence } \\
\text { Interval of the } \\
\text { Difference }\end{array}$} \\
& & & & & & \multicolumn{2}{c}{$\begin{array}{c}\text { Lower } \\
\text { Upper }\end{array}$} \\
kemampuan & 21.41 & 29 & .000 & 38.100 & 34.46 & 41.74 \\
$\begin{array}{l}\text { vocabulay pretest } \\
\text { kemampuan }\end{array}$ & $\begin{array}{r}78.68 \\
\text { vocabulay postes }\end{array}$ & 29 & .000 & 84.267 & 82.08 & 86.46 \\
\hline
\end{tabular}

\section{Discussion}

$\mathrm{Ho}=\mathrm{M} 1=\mathrm{M} 2$

$\mathrm{HI}=\mathrm{M} 1>\mathrm{M} 2$

Based on the above parametric test it can be concluded that the test is accepted because (sigma 000 result $<0.05$ sigma is accepted if less than 0.05 ) with the research question is there any improvement of student's vocabulary after the teaching program using flashcard, hypothesis accepted with sigma $000<0.05$.

\section{CONCLUSION}

This research was aimed to investigated the teaching activity about vocabulary using Flashcard to Young learner in the pre experimental method. The experiment gave a result that there is an improvement in students's vocabulary mastery after they were thaught by using Flashcard. The students could memorize and understand Englsih vocabulary more easily and be more interested to Learn English. This fact is contrast with students's achievement before they were thought by using flashcard.

The researchers have some suggestions for further study in the learning program of teaching vocabulary to the students in elementary school using Flashcards. Firstly, this is suggestion for further study to implicate the study in other skills, such as reading, speaking, listening and grammar teaching. Secondly, it is suggested to provide flashcard in interesting pictures to gain students's interest and make the learning process enjoyable. Thirdly, to make learning process more fun, it is suggested to blend the learning process using flashcard with playing vocabulary games. Overall, this teaching program is suggested to use flashcard in teaching vocabulary to young learners.

\section{ACKNOWLEDGMENTS}

Alhamdulillahirabbil'alamin. Praise to Allah Subhanahuwata'ala. Lord of the world who has given the writer his blessing and strength to finish this research paper. Peace and salutation are always for Rasulullah Shallahu'alaihi wasallam. During complementation this research, the writer thanked to many people who has giving encouragement and also support to finish this research. May this research give benefit in education and another researcher.

\section{REFERENCES}

Borg, W. (1979). Educational Research;AnIntroduction. New York London.

Brown, D. H. (2000). Brown, D. H. (2000). Principles of language learning \& teaching. (4th ed.). New York:Longman.(pp. 49-58). New York: Longman.

Kamil, M. L. and E. H. H. (2005). Teaching and Learning Vocabulary: Bringing Research to 
Practice.

Lewis. M. (1993). The Lexical Approach.

Richards, J. C. \& R. T. S. (2001). Approaches and methods in language teaching.

Verneer, A. (1992). Exploring the second language learner lexicon. In L. Verhoeven and J. H.A.

L. de Jong (Eds.) The Construct of Language Proficiency.

Wilkins, D. (1972). Linguistics in language teaching. London: Arnold. 